\title{
Citazioni architettoniche e urbane. La facciata della casa di Flaminio Ponzio a via Alessandrina
}

\author{
Gaia Lisa Tacchi \\ Emanuela Chiavoni
}

\section{Abstract}

Esistono connessioni remote tra spazi urbani animati da architetture appartenenti ad altri tempi, che possono essere svelati e analizzati attraverso la ricerca, lo studio, la costruzione di immagini e rappresentazioni, con il disegno in particolare. Si entra nel campo della poetica del frammento, del disegno di ricomposizione guidato dalla memoria dei luoghi, che lascia tracce del passato, più o meno visibili. Membra di città, in questo caso la città di Roma, che si spezzano e ricompongono in un altrove, secondo una logica forse incomprensibile. L'iconografia storica permette di connettere un'architettura a un'epoca, a una temperie culturale, il disegno dal vero di tracce incise dal passato nei luoghi connette una speculazione ad una situazione concreta, tangibile. L'analisi della trasposizione di una parte di un'architettura demolita, la facciata della casa di Flaminio Ponzio a via Alessandrina in un altrove, fa pensare a un testo architettonico di cui si è conservata una pagina, importante, ma con relazioni interrotte. Il disegno della memoria consente la rilettura e la connessione, ritrova la relazione e la contestualizzazione di un importante brano di città.

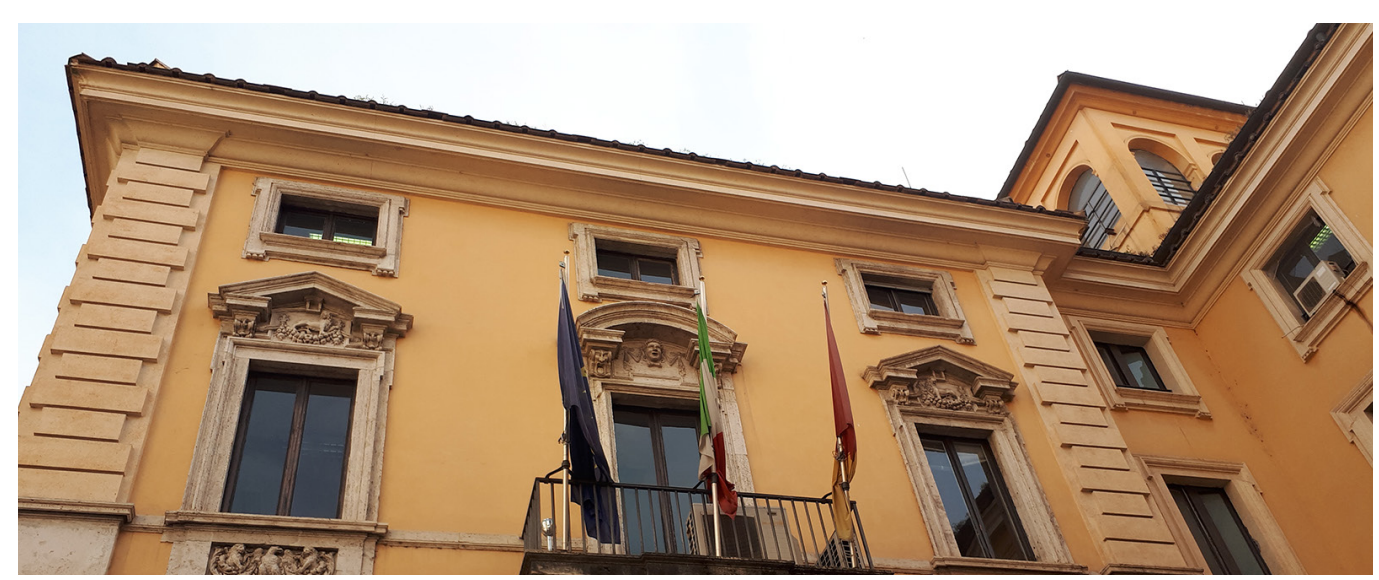


"Quella casa assai vaga di contro al Monastero di S. Urbano in Via Alessandrina, la di cui facciata è ordinata sopra il basamento di un piano nobile, con un poco di mezzato sotto il cornicione, fu l'abitazione dell'illustre architetto lombardo,

Flaminio Ponzio"

[Mazio I872, pp. 330, 33 I].

\section{Documentazione storica, bibliografica e iconografica}

La casa di Flaminio Ponzio in via Alessandrina sembra essere stata la prima opera certa dell'architetto a Roma. Demolita in occasione dell'apertura di via dei Fori Imperiali nel I933, ne è stata rimontata soltanto la facciata in piazza S. Maria in Campitelli vicino alla chiesa di S. Rita, anch'essa ricostruita dopo essere stata asportata dalle pendici del Campidoglio. Flaminio Ponzio, del quale si conosce poco sia della vita sia dei lavori in giovinezza, inizia la sua carriera aderendo a moduli tardo cinquecenteschi lombardi, propri della sua formazione, e fiorentini, per poi evolvere, in alcune opere, verso canoni anticipatori del barocco.

Può risultare utile ai fini di un'analisi dell'edificio una datazione quanto più precisa per poter capire in quale momento della temperie architettonica romana viene pensato e in quale momento dell'esperienza e della maturazione dello stesso Ponzio.

Attraverso l'osservazione delle piante storiche di Roma [I] si può facilmente dedurre che la casa di Ponzio compare sempre nelle piante successive al I600 [Maggi I625; Matteo Gregorio De Rossi 1668; Greuter 1618] (fig. I).

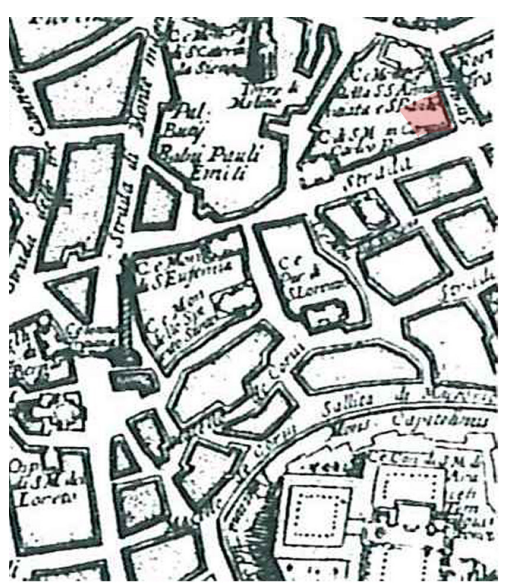

Pianta di Roma del Nolli. 1748

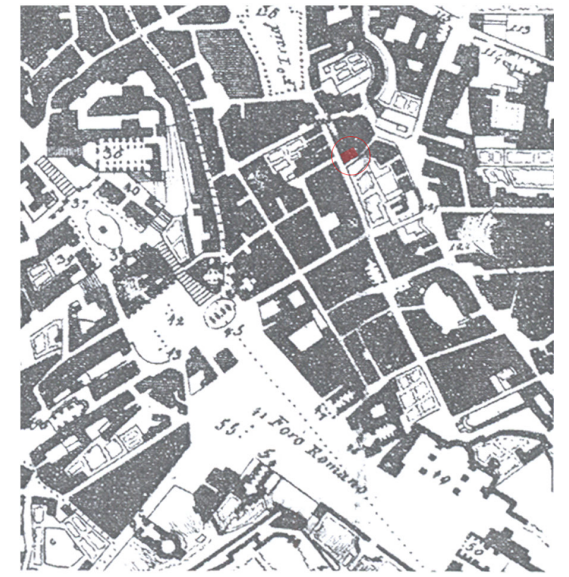

Pianta di Roma di Matteo Gregorio De Rossi, 1668

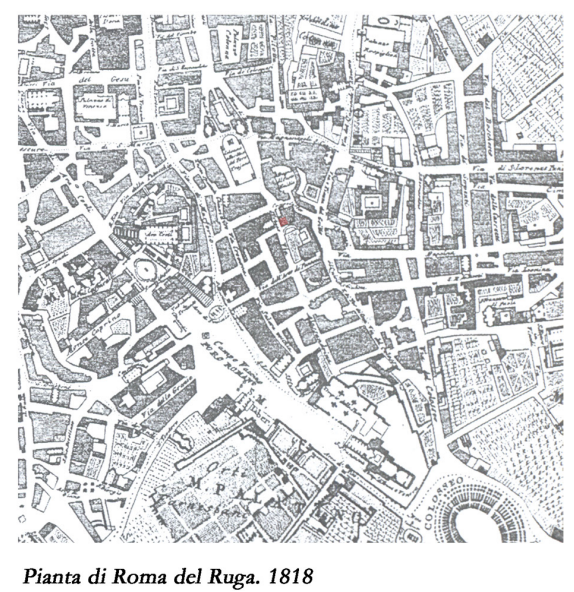

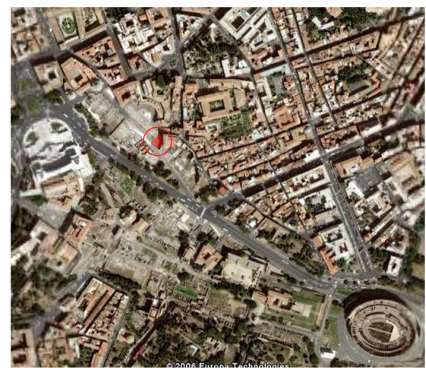

Foto aerea della situazione attuale dell'area dei Fori Imperiali 
La posizione originaria dell'edificio è stata individuata in seguito ad uno studio [Prisco, Mercurio 1982, pp. 85-98] in cui si fa riferimento al recupero di importanti documenti inediti relativi alla demolizione dei fabbricati insistenti su via Alessandrina: materiale redatto durante le demolizioni del Ventennio seguite e dirette in quell'area da Corrado Ricci con l'aiuto dell'architetto Mascanzoni, che ha effettuato in particolare i rilievi dei prospetti della strada in oggetto. Sulla via Alessandrina, nellisolato tra via di Campo Carleo e via Bonella, in corrispondenza dell'esedra che volgeva verso nord del porticato del foro di Augusto, insieme all'orto di SS. Annunziata che mostrava sulla strada un alto muraglione, c'era la casa di Flaminio Ponzio, rilevata anche in pianta prima della demolizione da Luigi Crema (figg. 2, 3). Si tratta di un edificio di modeste dimensioni, un'abitazione per una famiglia borghese, capeggiata da una figura professionale emergente, anche se non appartenente all'aristocrazia. E un progetto in cui la libertà di espressione può essere espressa più che in altri contesti: progettare la propria casa probabilmente dà la possibilità all'architetto di sperimentare, di rappresentare in architettura se stessi. Flaminio Ponzio in un lotto con una forma particolare, che lo vincolava di certo, realizza un piccolo edificio, risolto in modo coerente e, si potrebbe dire, grazie a "la capacità formativa dell'imitazione" [Benedetti 1993, p. 36] [2]: in questo piccolo edificio si sente, specialmente nell'organizzazione planimetrica, l'eco delle esperienze sangallesche dei palazzi romani, che sono giunti a un tale livello di compiutezza e di sintesi tra funzione e forma, tra esigenze funzionali e materiali, da generare un 'tipo'.

Si diceva che l'opera nascesse da una somma di elementi e si risolvesse in una pianta dalla forma singolare, che segue la sagoma trapezoidale del lotto. Ponzio opera la tipica tripartizione, con ingresso al centro, operando in modo inizialmente simmetrico, poi sfrutta la strozzatura del lotto sul lato destro e in quello spazio angusto vi posiziona la scala, a pianta semicircolare per occupare minor spazio, senza imporre limiti eccessivi alla qualità della percezione spaziale. Nel proseguire l'analisi occorre dire che ci sono pervenuti due diversi disegni della pianta del piano terra dell'edificio; non se ne sono trovati dei piani superiori. La pianta più antica (quindi più vicina alla versione di Flaminio Ponzio, volendo essere certi della fedeltà del rilievo all'originale) del Letarouilly [3] (1868) e quella più recente (fig. 4), redatta poco prima della demolizione e pubblicata da Luigi Crema nel 1939. Nella prima pianta il corridoio giunge ad un ambiente trapezoidale ampio, un cortile con un solo lato porticato e gli altri tre semplicemente, ma elegantemente, inquadrati da una teoria di ordini architettonici ciechi, disegnati su paraste addossate al muro chiuso (almeno al pian terreno).

Fig. 2. Fotografia dell'edificio prima della demolizione al numero civico 7 in via Alessandrina [Delli 2007, vol. I].

Fig. 3. Fotografia dell'edificio prima della demolizione al numero civico 7 in via Alessandrina [Magni | 91 | - |3, vol. II, tav. |2].
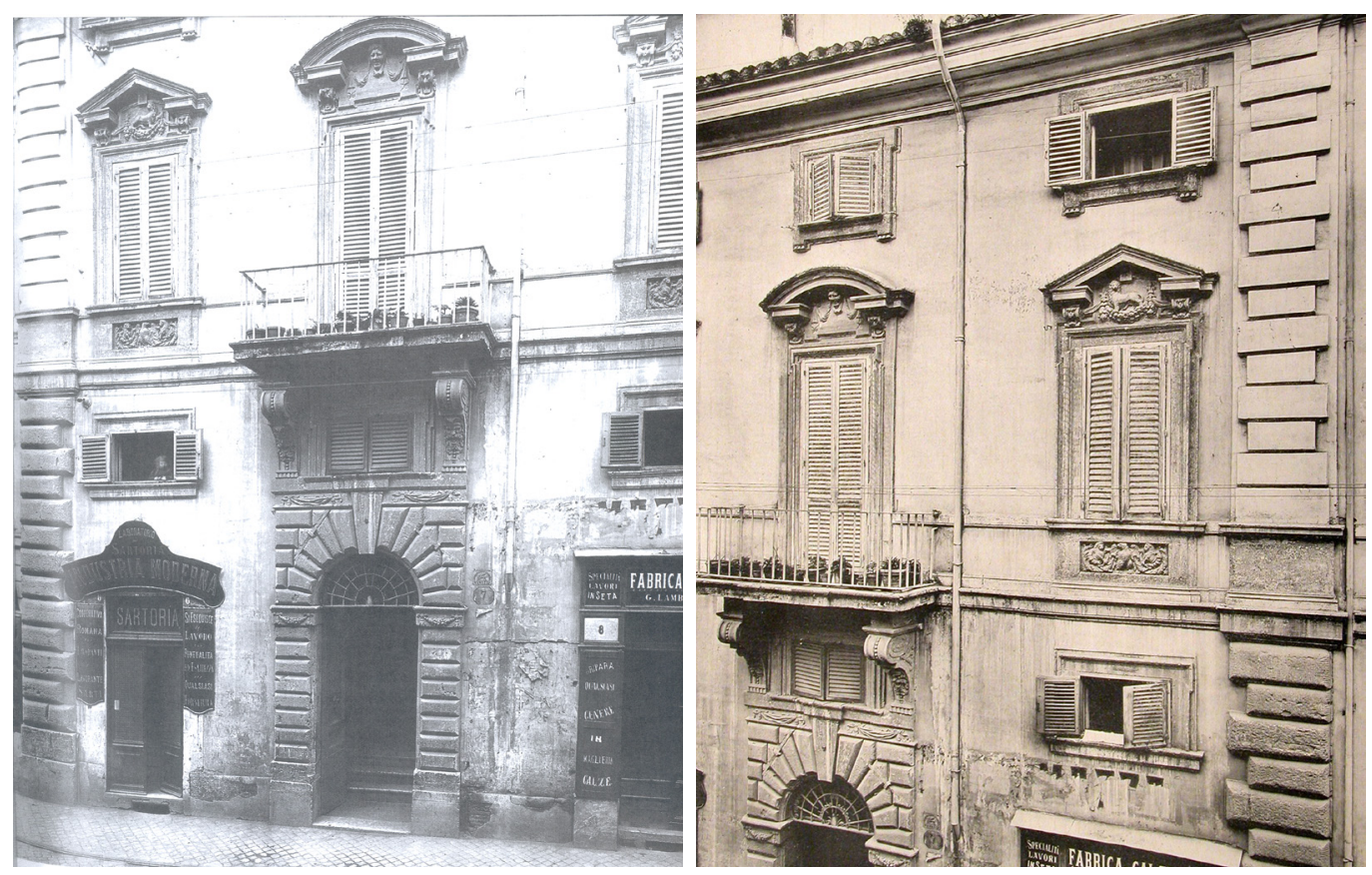
Fig. 4. In alto: Pianta di una casa in via Alessandrina [Letarouilly 1868, tav. 26] in basso: Casa in via Alessandrina, Rilievo da L. Crema.
Uno spazio che evolve plasticamente ed espressivamente da spazio di risulta a cortile, con la profondità percettiva risolta dall'ampio porticato sorretto da forti pilastri inquadrati anch'essi nell'ordine complessivo. A proposito di questo disegno del Letarouilly, è importante notare che le aperture del fronte sulla strada, laterali all'ingresso, che nei rilievi e nelle foto d'epoca sono porte d'ingresso ad attività commerciali, sembrano finestre per la presenza dell'ampia strombatura e dei davanzali. Si notano inoltre nella pianta del Letarouilly una serie di strutture, colonnine probabilmente (sono viste in proiezione, dunque basse), che delimitano uno spazio longitudinale davanti all'ingresso. Si tratta di una specie di piattaforma su due livelli a cui si accede con dei gradini: tre per salire al livello di fronte all'ingresso dell'abitazione e due per salire lateralmente al livello più basso sotto le finestre.

La pianta di Crema mostra un'evoluzione dell'organizzazione planimetrica dell'edificio: un ampliamento con un ulteriore ingresso sulla strada, facente parte di un corpo di fabbrica che non compare in alzato in una nota stampa del Vasi dedicata alla chiesa di S. Maria in campo Carleo [4] (fig. 5). Si tratta di un corridoio piuttosto ampio, una galleria voltata che segue la direzione inclinata del lotto trapezoidale; detta galleria giunge (addossandosi ai muri antichi, come spiega Crema) al cortile che, pur presentando ancora il porticato, non è più inquadrato nell'ordine architettonico.

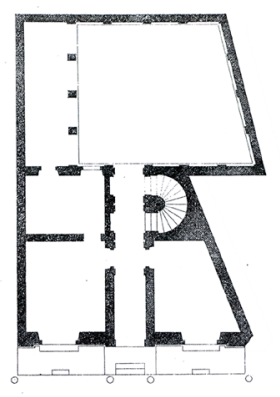

Plan dune Maison Yia Mlessandriza $=1$...e

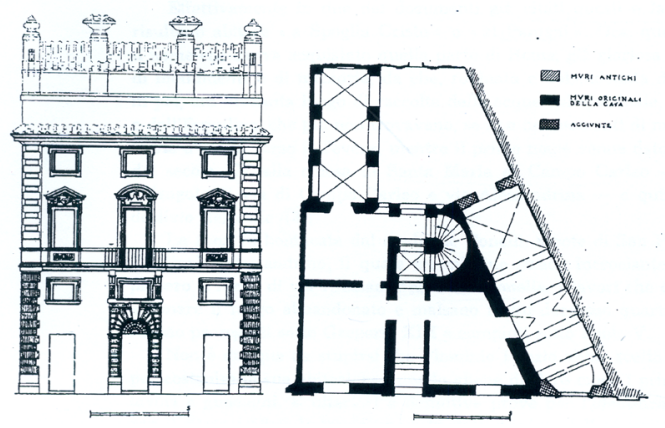

Crema ci fa pervenire anche il disegno del prospetto originale, escludendo quello del corpo di fabbrica laterale aggiunto, che tra l'altro doveva per forza essere stato costruito sui muri antichi dell'esedra nord del foro di Augusto. Possiamo avere un'idea dei due corpi di fabbrica affiancati grazie ai rilievi effettuati su tutta la quinta stradale della via Alessandrina (e non solo) prima delle demolizioni dall'architetto Mascanzoni [5] (figg. 6, 7), figura di riferimento di Corrado Ricci, direttore dei lavori di demolizione e di nuova sistemazione dell'area ad area archeologica.

II prospetto è composto verticalmente di due parti: la parte basamentale e quella relativa al piano nobile con mezzanino. Nelle immagini d'epoca a disposizione, al di sopra del cornicione si nota una ulteriore struttura, forse una loggia o un lavatoio negli anni murato che poi presentava delle finestre, quindi adibito ad abitazione. Nel suo rilievo, Crema rappresenta questa parte come un'alta loggia aperta con alti pinnacoli di coronamento; nella stampa del Vasi più volte citata compare, ma è già chiusa e presenta delle finestre. 
La partizione in orizzontale del prospetto è sobria e discreta, consistendo soltanto nella fascia marcapiano e nella leggera modanatura che sottolinea il davanzale delle finestre del piano nobile, che presentano un'elegante decorazione a bassorilievo. Questa fascia visiva è sottolineata dalla ringhiera dell'unico balcone centrale del prospetto.

La facciata presenta una fascia bugnata alle estremità per tutta la sua altezza, nella parte basamentale è più massiccia e rigonfia, nella parte superiore il bugnato è piatto e liscio e si trasforma in una modanatura ornamentale che invece di sottolineare l'angolo, l'alluso angolo, lo smaterializza progressivamente verso l'alto: essa è infatti composta di rettangoli alternativamente più stretti e più larghi, che formano un limite esterno, un confine sfumato, una sorta di compenetrazione a sottolineare la continuità della cortina stradale.

Nella casa di Flaminio Ponzio lo stretto connubio tra il portale, in bugnato rustico che produce una massa ricca di chiaroscuri, e il volume del balcone impostato su mensoloni decorati che, a loro volta, racchiudono la finestra centrale del mezzanino, produce un insieme ad incastro con forte valore ascensionale che ricorda una soluzione esemplare di un altro portale, quello di palazzo Serlupi Crescenzi in via del Seminario, opera del I 585 di Giacomo della Porta.

Così in questo piccolo palazzo d'abitazione si sente un confluire di echi e di idee provenienti da diverse esperienze, che s'intersecano più o meno lontane nel tempo, a testimoniare la viva partecipazione creativa di Flaminio Ponzio, un architetto, secondo alcuni autorevoli studiosi, che si inserisce con sensibilità e sobrietà tra coloro che preannunciano il passaggio tra le soluzioni rinascimentali e manieriste e quelle più propriamente barocche.

Fig. 5. Stampa del Vasi di S. Maria in Campo Carleo, piazza Campitelli [Vasi 1756]. Evidenziata la casa di Flaminio Ponzio.

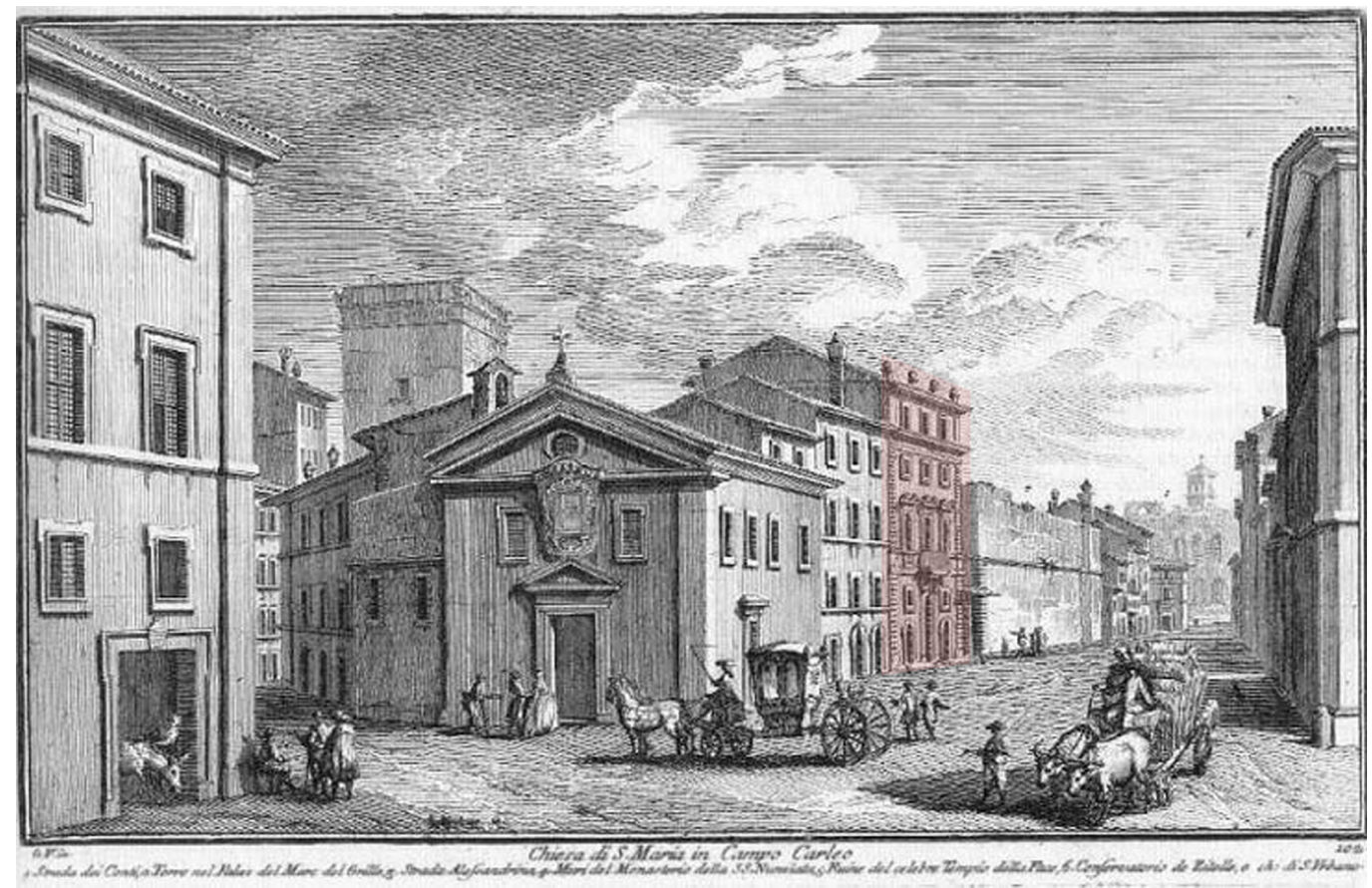

\section{La trasposizione, ovvero la demolizione e la ricostruzione altrove}

Crema afferma che "l'edificio verrà ricostruito"; in realtà si tratta della ricostruzione della sola facciata [6]. Ciò implica la scomparsa di una parte di un'opera architettonica che, con ogni probabilità, implica la perdita del tutto. Si annulla la sintesi, la motivazione, l'unità formativa, l'intenzionalità architettonica. White pubblica la pianta del nuovo edificio cui adesso appartiene la facciata copia di quella della casa di Flaminio Ponzio: è evidente la diversità totale dell'impianto planimetrico, sproporzionato e abnorme (fig. 8). 
Fig. 6. Rilievi dei prospetti in via Alessandrina prima delle demolizioni a cura dell'architetto A. Mascanzoni [Prisco, Mercurio

Fig. 7. Pianta del catasto pontificio con localizzazione dei lotti occupati
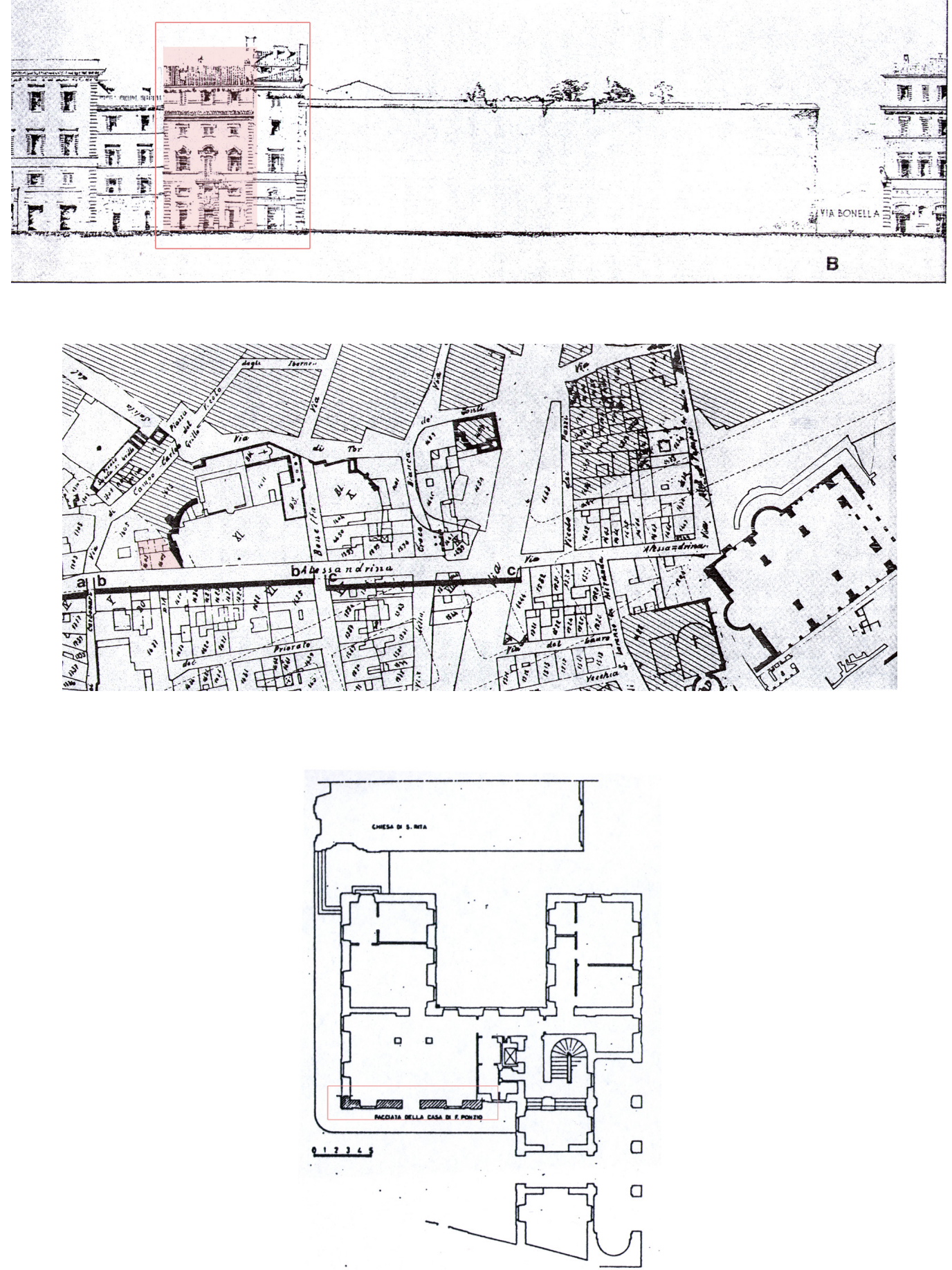
Inoltre, ciò che ha determinato la scomparsa o comunque la modifica definitiva della percezione che si poteva avere della facciata è lo spaesamento, lo spostamento del prospetto in un diverso contesto, che attualmente forma una quinta importante di piazza Campitelli, della facciata di Ponzio, che era pensata per una quinta stradale con una forte peculiarità longitudinale (fig. 9).

La ricostruzione in ogni caso è frutto di una serie di interpretazioni successive, da quella del rilievo in cui si decide qual era il progetto originario di Flaminio Ponzio, da salvare, a quella del trasporto, a quella dell'edificazione. Insieme e dettagli architettonici si mettono e si omettono, scelte che appartengono inevitabilmente all'epoca in cui vengono effettuate.
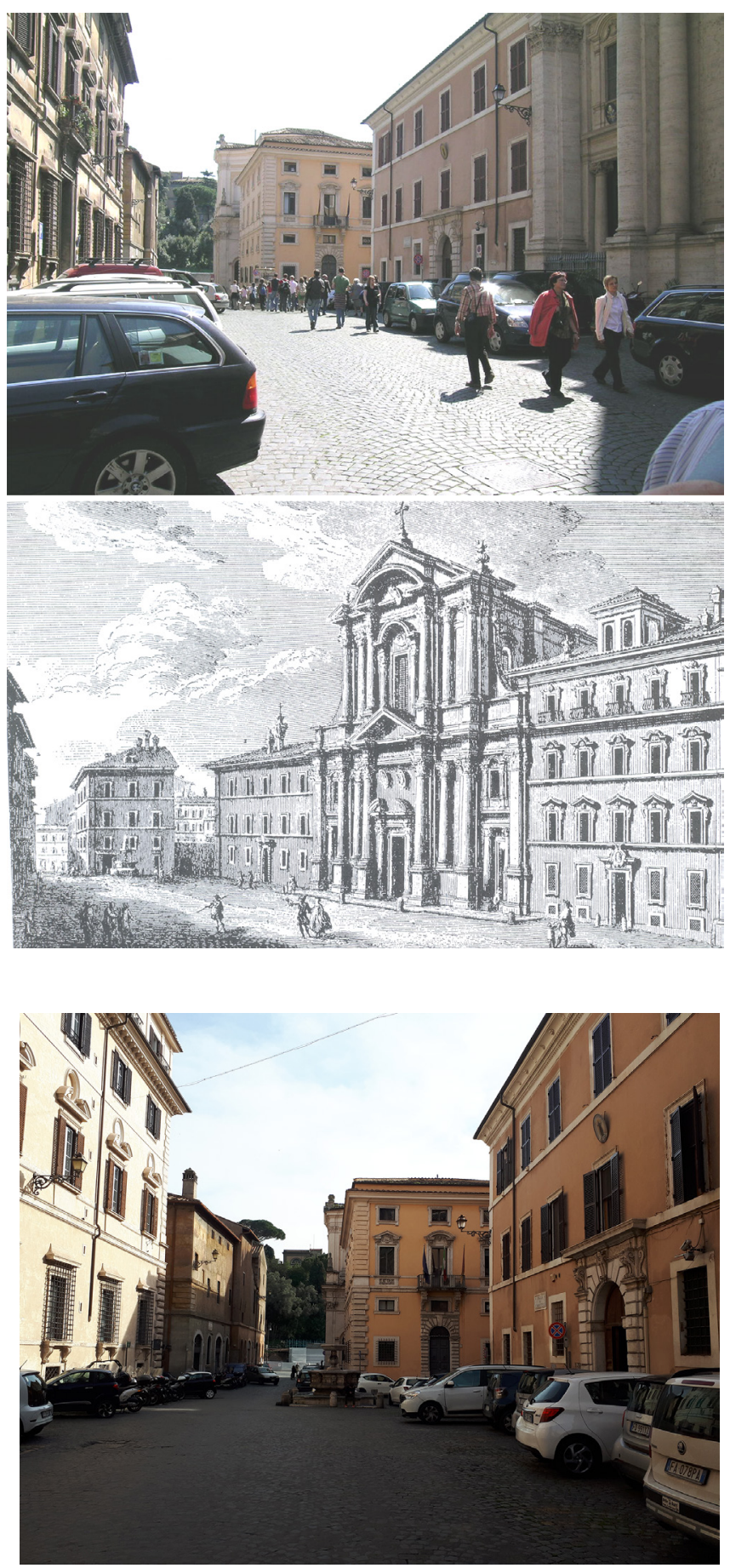
A titolo esemplificativo basti osservare le aperture laterali al piano terra: sono finestre incorniciate, dunque non porte come nelle foto d'epoca e nei rilievi novecenteschi.

Dalla pianta del Letarouilly, come si è detto, si può facilmente dedurre, per la presenza di davanzali disegnati, che dette aperture fossero proprio finestre; lo stesso Crema conferma questa ipotesi. Del resto, le aperture dei negozi non presentano cornici, il che è piuttosto singolare se si osserva la cura dei dettagli di tutta la composizione della facciata. La volontà del ricostruttore non era dunque solo quella di ricostruire la facciata, ma probabilmente di ripristinare il progetto originario di Flaminio Ponzio, sulla base delle testimonianze iconografiche a disposizione (fig. 10).

L'impressione che si ha osservando la facciata ricostruita è quella di trovarsi di fronte ad un falso o meglio, ricordando uno scritto di Cesare Brandi [Brandi 1963] [7], ad una copia: in effetti non si è più al cospetto di un'opera d'arte così come era stata concepita, ma ad una sua riproduzione, senza avere la pretesa di considerarla ancora come un'opera originale.

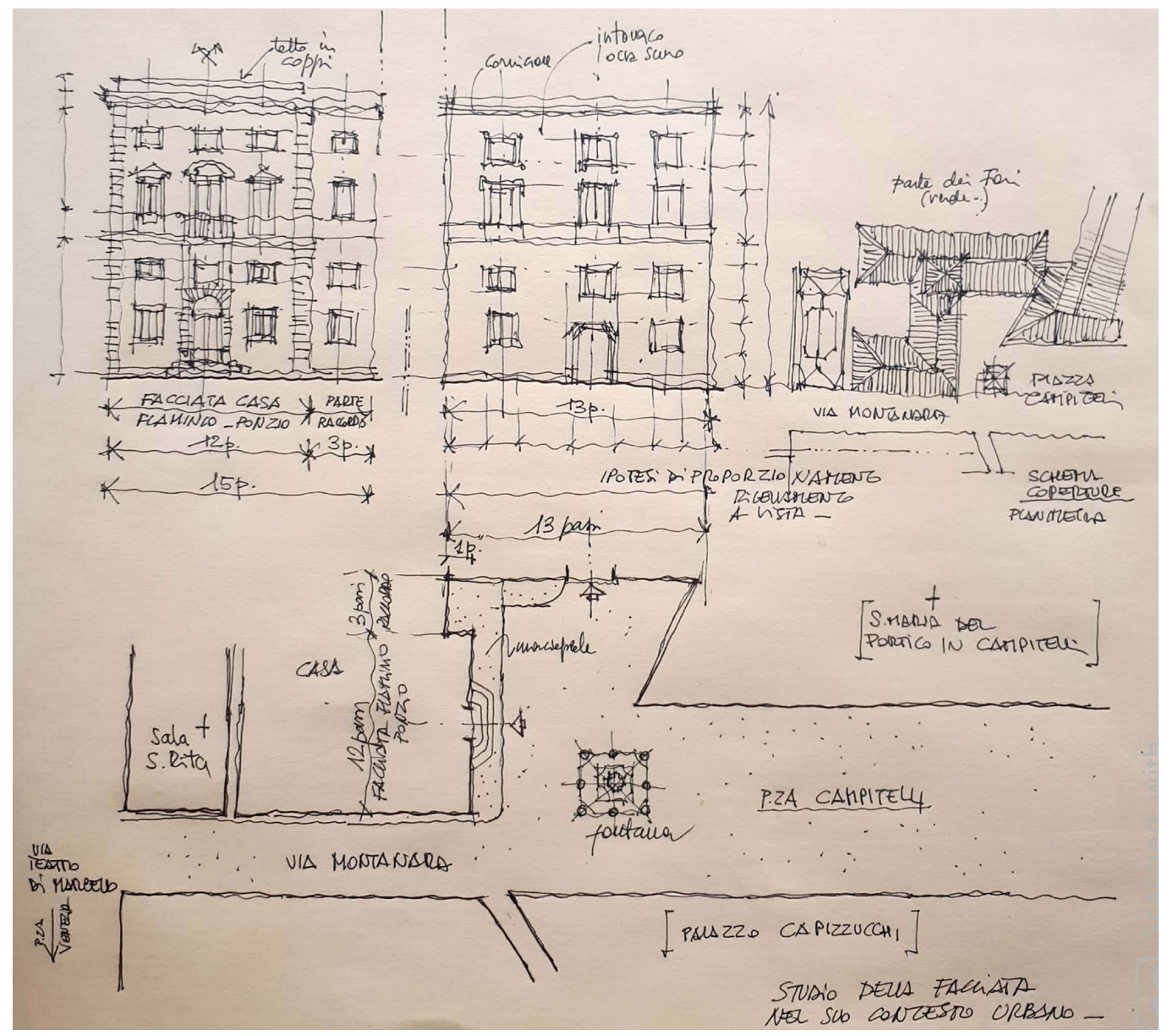

\section{Riflessioni finali, conclusioni}

Numerosi sono i sistemi per indagare e riflettere sulle modificazioni della città, ma il processo del disegnare ha dimostrato anche in questa complessa analisi che è tra i metodi più strutturati e sensibili per la conoscenza perché consente di orientarsi rispetto ai diversi avvenimenti storici che hanno stravolto gli spazi urbani. II rapporto tra disegno e linguaggio trascina in maniera completa chi lo compie; è un lavoro lento, paziente, sistematico (figg. I I, I2).

II filo conduttore dello studio è stato la memoria; un'attività di apprendimento di dati diversi derivanti dall'ambiente esterno appresi attraverso gli organi di senso e poi elaborati sotto forma di esperienze per la comprensione dei fenomeni e lo sviluppo dell'intelletto e dell'ingegno. 
Questa attività di lettura critica ha interpretato le nuove relazioni urbane derivate dai cambiamenti partendo dagli aspetti percettivi e assumendone i diversi significati anche degli elementi caratterizzanti l'architettura.

La memoria è consegnata in questo caso alle fonti scritte e disegnate, alle fotografie storiche, alla stratificazione dei luoghi sui quali si è agito con una pianificazione che ha tenuto conto di aspetti diversi da quelli del restauro urbano come lo conosciamo oggi, in cui le trasformazioni debbano tenere conto della storia e dell'essenza dei luoghi. II disegno ci rende capaci di analizzare il presente per farlo dialogare con il passato, in termini grafico-analitici, creare dunque una connessione. Per entrare nel merito, lo spostamento dell'opera di Flaminio Ponzio è stato parziale, poiché è stata ricostruita solo la facciata della casa da lui progettata. La casa era disposta in origine lungo un rettilineo e affiancava un muro di confine del convento della SS. Annunziata, anch'esso demolito. A livello percettivo l'opera di Flaminio Ponzio si riduceva alla facciata, che ripeteva uno schema ritmico di altre facciate lungo la strada e non aveva altri annessi che non sé stessa, non emergendo dalla linearità del percorso. Ciò che può essere analizzato oggi attraverso il disegno, conoscendo la storia dell'edificio e della sua migrazione, è la percezione che si ha di esso nella recente sistemazione architettonico-urbana; e non solo, si può studiare la qualità degli elementi architettonici che sono stati ricostruiti e controllarli confrontandoli con disegni e fotografie.

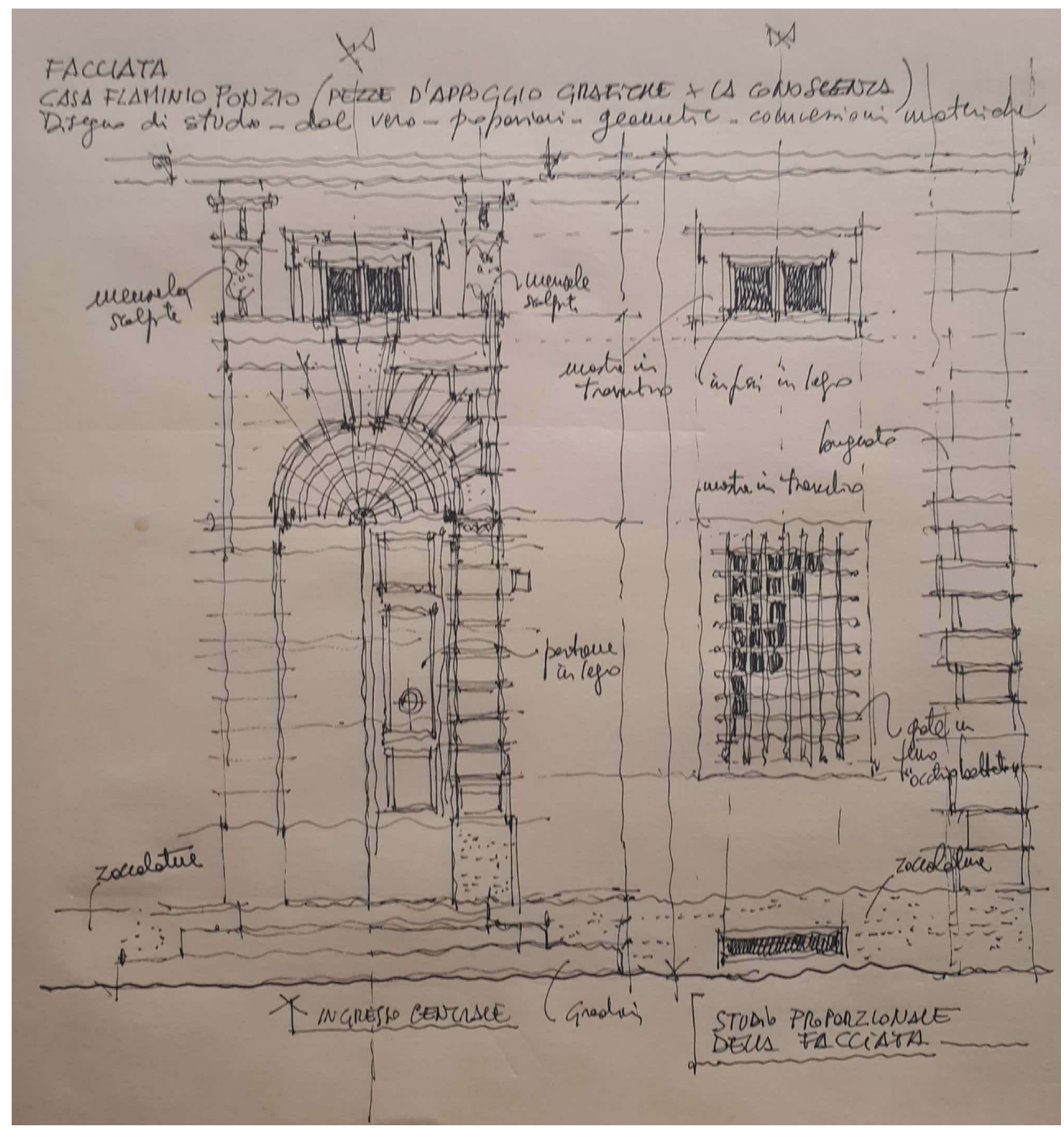


Appare fin dal primo momento che ora la facciata è posta in posizione ortogonale rispetto all'asse stradale su quale si attesta l'avancorpo su cui è stata montata. Ciò produce un appiattimento della percezione delle modanature e soprattutto scopre i fianchi e le connessioni angolari che non appaiono progettate in armonia. Un altro elemento che emerge di inserimento nel contesto, in particolare attraverso l'analisi grafica, è lo stravolgimento delle proporzioni tra il rettangolo della facciata in esame e quelle adiacenti e che la fronteggiano. II senso di spaesamento e fissità che si prova, quando le sfumature della storia e della memoria vengono meno, prende concretezza attraverso il disegno, che spiega, racconta e, in alcuni casi disvela le contraddizioni percettive di trasformazioni, come questa, fortunatamente graficamente documentate.

\section{Note}

[I] Le piante storiche di Roma da A.P. Frutaz, Le Piante di Roma, Roma, 1962, II vol.: Pianta del Greuter, I6 I 8; Pianta del Maggi, 1625; Pianta di Matteo Gregorio De Rossi, I 668; Pianta di G.B. Falda, I676; Pianta del Tempesta, I693; Pianta di Roma del Nolli, 1748; Pianta del Ruga, 1818.

[2] La teoria filosofica, elaborata da Luigi Pareyson, viene richiamata più volte da Benedetti e da altri studiosi, nel tentativo di comprendere le leggi formative dell'opera d'arte, o, il che è lo stesso, dell'architettura. Nella fattispecie l'autore fornisce un'ipotesi di possibile rapporto tra il 'tipo' e l'opera singola, che nasce il seguito ad un processo imitativo positivo, operativo e creativo anch'esso.

[3] Pianta di una Casa in Via Alessandrina [Letarouilly | 868, tav. 26].

[4] Stampa del Vasi di S. Maria in Campo Carleo, Piazza Campitelli [Vasi I756]. In effetti la casa di Flaminio Ponzio era la penultima prima dell'inizio del muraglione che racchiudeva l'orto di SS. Annunziata, l'ultimo era appunto un altro corpo di fabbrica di cui faceva parte questo nuovo ingresso.

[5] Prospetti di Via Alessandrina redatti dall'architetto A. Mascalzoni prima della demolizione [Prisco, Mercurio 1982, p. 90].

[6] A proposito di Piazza Campitelli:" "Il fabbricato moderno al numero 6 conserva la facciata rimontata della Casa di Flaminio Ponzio eretta su suo progetto nel I 600 in Via Alessandrina e demolita nel I 933 per l'apertura diVia dell'Impero": Touring Club Italiano (2004). Roma. Milano:Touring Club Italiano, p. 494.

[7] Brandi 1963: Appendice, Falsificazione.

\section{Riferimenti bibliografici}

Benedetti Sandro (1993). Fuori dal Classicismo. Il sintetismo nell'architettura del Cinquecento. Roma: Bonsignori.

Brandi Cesare (1963). Teoria del restauro. Torino: Einaudi.

Chiavoni Emanuela (2014). Drawings on paper. Digital historical archives of the former Radaar Department at the University Sapienza School of Architecture in Roma. In SCIRES-IT, 4, 2, 2014, pp. 117 - 126.

Chiavoni Emanuela, Diacodimitri Alekos, Di Pietro Martinelli Paolo (2018). New Fruition Possibilities for the Historical Archive of Architectural Drawings in Rome. In Inglese Carlo, Ippolito Alfonso (eds.). Analysis, Conservation, and Restoration of Tangible and Intangible Cultural Heritage. Hershey PA (USA): IGI Global, 20 I8, pp. 403-430.

Delli Sergio (2007). Le strade di Roma. Roma: Newton Compton.

Docci Mario, Maestri Diego (2009). Manuale di rilevamento architettonico e urbano. Roma: Laterza.

Letarouilly Paul (I 795- I855). Edifices de Rome moderne. Palais et Maisons, I. London: J. Tiranti \& co.

Magni Giulio (19|1-19|3). II Barocco a Roma nell'architettura e nella scultura decorativa. Torino: Crudo. Mazio Luigi (1872). Studi storici, letterari e filosofici. Roma: Editr. Romana.

Prisco Luigi, Mercurio Giovanni (1982). Via Alessandrina a Roma: assenza del passato? In Storia architettura, 2, 1982,5 , pp. 85-98. Vasi Giuseppe (|747-176I). Delle Magnificenze di Roma Antica e Moderna.

\section{Autori}

Gaia Lisa Tacchi, Sapienza Università di Roma, gaialisa.tacchi@uniromal.it

Emanuela Chiavoni, Sapienza Università di Roma, emanuelachiavoni.uniromal.it

Per citare questo capitolo:Tacchi Gaia Lisa, Chiavoni Emanuela (2020). Citazioni architettoniche e urbane. La facciata della casa di Flaminio Ponzio a Via Alessandrina/Architectural and urban citations. The façade of Flaminio Ponzio's House in Via Alessandrina. In Arena A., Arena M., Brandolino R.G., Colistra D., Ginex G., Mediati D., Nucifora S., Raffa P. (a cura di). Connettere. Un disegno per annodare e tessere. Atti del $42^{\circ}$ Convegno Internazionale dei Docenti delle Discipline della Rappresentazione/Connecting. Drawing for weaving relationships. Proceedings of the 42th International Conference of Representation Disciplines Teachers. Milano: FrancoAngeli, pp. 2758-2777. 


\title{
Architectural and Urban Citations. The Façade of Flaminio Ponzio's House in Via Alessandrina
}

\author{
Gaia Lisa Tacchi \\ Emanuela Chiavoni
}

\section{Abstract}

The remote links that exist between urban spaces embellished by architectures of yesteryear can be revealed and analysed not only by performing researches and studies, but also by creating images and representations, in particular by using drawing. It involves the field of the poetics of fragments, of drawing a recomposition inspired by the memory of places that leave more or less visible traces of the past. Parts of the city, in this case the city of Rome, that are broken down and reassembled elsewhere, based on a perhaps incomprehensible logic. Historical iconography enables us to link an architecture to an age and cultural climate; the life drawing of signs engraved by the past in certain places links speculation to a material, tangible situation. Analysing part of a demolished architecture -the façade of Flaminio Ponzio's house in via Alessandrina- after it has been transposed elsewhere, brings to mind an architectural book in which an important page has been preserved, but with sporadic relationships. Drawing memory enables reinterpretation and connection; it rediscovers the relationship and contextualisation of an important part of the city.

Keywords

drawing, memory, documentation, transformations, Flaminio Ponzio's house.

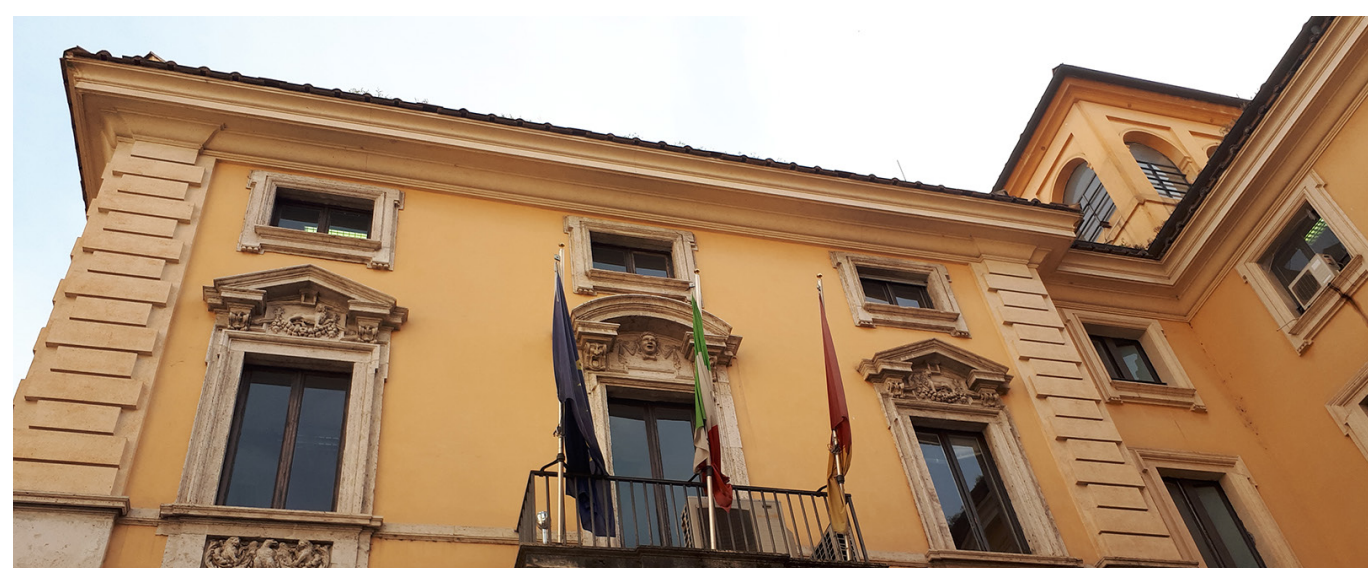


"The rather non-descript house facing the Monastery of St. Urban in Via Alessandrina, with a façade above the base of a piano nobile and a little mezzanine under the cornice, was home to the illustrious Lombard architect, Flaminio Ponzio" [Mazio I872, pp. 330, 33 I].

History. Essential bibliographic and iconographic documentation

Flaminio Ponzio's house in via Alessandrina is the first known work built by the architect in Rome. While the entire house was demolished when via dei Fori Imperiali was built in 1933, the façade was reassembled in piazza S. Maria in Campitelli near the church of St. Rita, also reassembled after having been removed from the hillside of the Campidoglio.Very little is known about Flaminio Ponzio's life and early works; at the outset of his career he was inspired by the late sixteenth-century Lombard modules he had studied during his training, as well as by Florentine modules. Some of his later works reveal he subsequently veered towards canons anticipating the Baroque.

A more precise dating may be useful when analysing the building since it reveals not only the architectural climate that existed in Rome at the time, but also Ponzio's own personal experience and maturity. (Iconographical documentation, maps of Rome).

Examining the old maps of Rome [ $\mathrm{I}$ ] shows that Ponzio's house was always present in maps drafted after 1600 [Maggi 1625, Matteo Gregorio De Rossi 1668, Greuter I6 I 8] (fig. I).

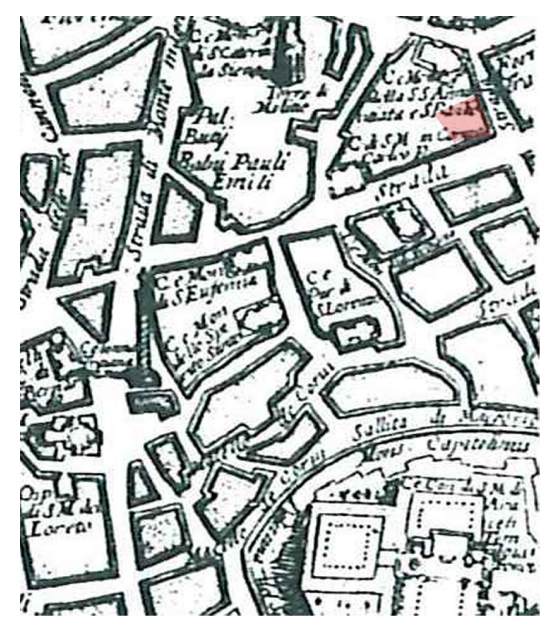

Pianta di Roma del Nolli. 1748

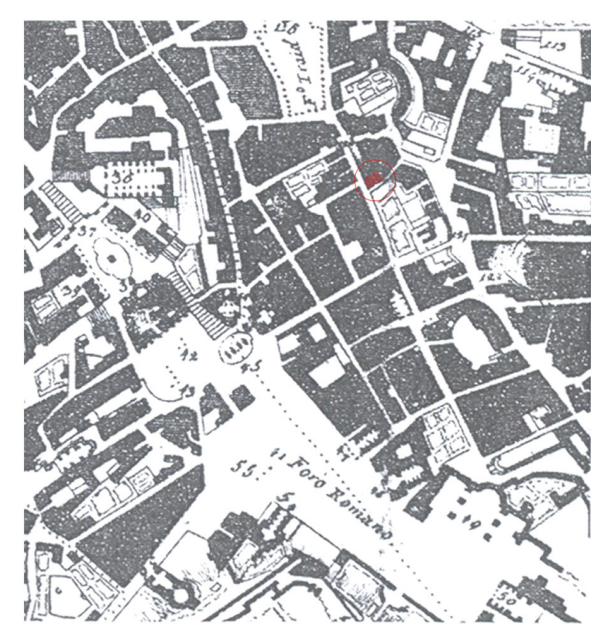

Pianta di Roma di Matteo Gregorio De Rossi, 1668

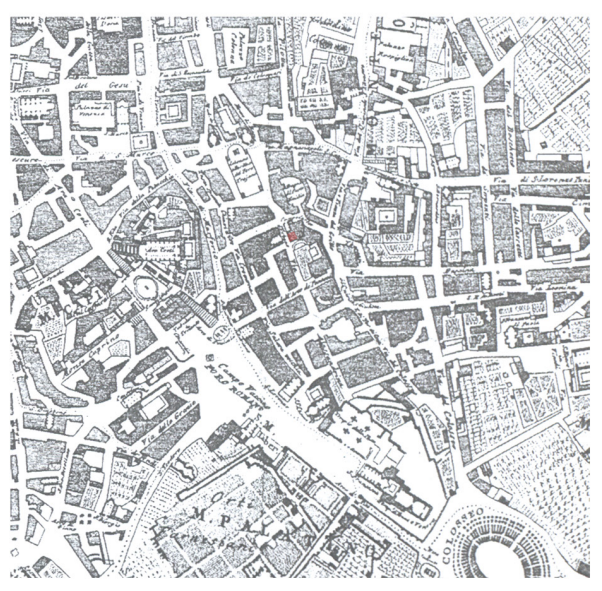

Pianta di Roma del Ruga. 1818

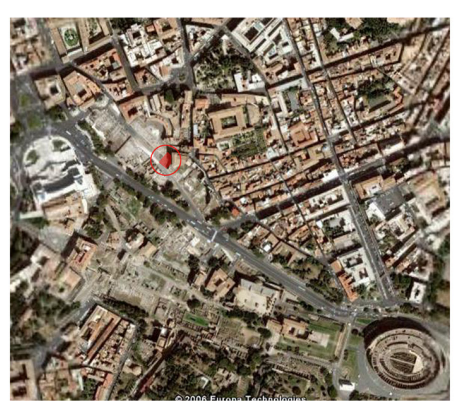

Foto aerea della situazione attuale dell'area dei Fori Imperiali 
A study [Prisco, Mercurio 1982, pp. 85-98] of important unpublished material regarding the demolition of buildings along via Alessandrina allowed us to identify the building's original location. The documents were drafted during the demolition executed during the Fascist period and supervised by Corrado Ricci, assisted by the architect Mascanzoni who was responsible for surveying the elevations of the roads in question. Flaminio Ponzio's house stood along via Alessandrina, in the block between via di Campo Carleo and via Bonella, next to the north-facing exedra of the portico of the forum of Augustus and the orchard of St. Annunziata with its high wall bordering the road. The house was also shown (pre-demolition) on the map by Luigi Crema (figs. 2, 3).

This small building was home to a middle-class but not aristocratic family; the head of the family was an up-and-coming architect. In this project freedom of expression could be used more than in other contexts: designing one's own house probably allowed Ponzio to experiment and represent himself in the architecture. Although he was undoubtedly limited by the irregular-shaped lot, one could say he rationally designed a small building thanks to the "formative ability of imitation" [Benedetti 1993, p. 36] [2]: the building, and especially its plan, echoes Sangallo's designs for buildings in Rome; the latter were so complete, combining function and form as well as functional and material requirements, they created a 'type'. The work is the sum total of elements that ultimately merge to form a unique plan following the trapezoidal shape of the lot. Ponzio chooses a typical tripartition, with a central entrance, initially with a symmetrical design, but then he exploits the narrowing of the right side of the lot and positions the staircase in that cramped space, designing a semi-circular staircase so that it occupies less space but without excessively curtailing the quality of the spatial perception. While continuing our analysis we discovered two different drawings of the ground floor, but none of the upper floors. The oldest plan is by Letarouilly [3] (1868) (therefore closer to the version by Flaminio Ponzio, so that we were sure the survey reflected the original) while the more recent plan (fig. 4) drafted shortly before its demolition is by Luigi Crema who published it in 1939. In the former the corridor leads to a big trapezoidal area, a courtyard with a portico on one side; the other three sides are simply but elegantly part of a mix of blind architectural orders drawn on pilasters resting against the wall without windows (at least on the ground floor).

Fig. 2. Photograph of the building at $n .7$ of Via Alessandrina before it was demolished [Delli 2007, vol. I].

Fig. 3. Photograph of the building at $n$. 7 of Via Alessandrina before it was demolished [Magni | 9| | - |3, vol. II, tav. |2].
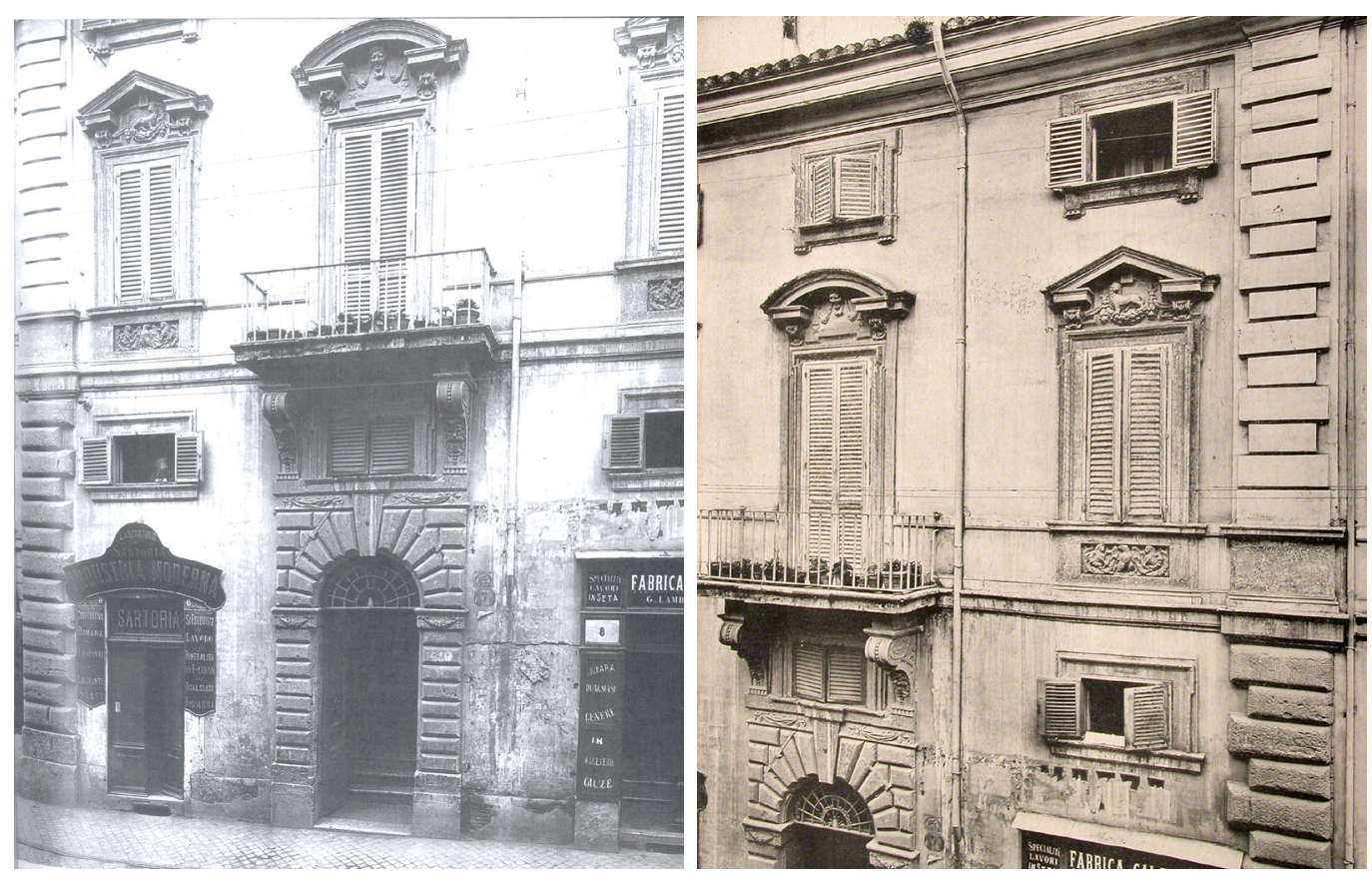
A space that plastically and expressively evolves from a courtyard-shaped leftover area; the perceptive depth was solved by the big portico and its massive pilasters, also included in the overall order. It's important to note that in Letarouilly's drawing the openings onto the street on either side of the entrance (which in the surveys and old photographs are shop entrances) appear to be windows due to the presence of accentuated splaying and sills. Also note the series of structures, probably small columns (seen in projection and therefore low) along the longitudinal space in front of the entrance. It is a sort of two-level platform accessed by several steps: three to reach the level in front of the entrance to the house and two to move sideways to the lower level under the windows.

Crema's plan reveals changes in the building's plan: an enlargement with another entrance along the street. The latter is part of another building; its elevation is not present in Vasi's famous print of the church of S. Maria in campo Carleo [4] (fig. 5). It is a rather wide corridor, a vaulted gallery following the slant of the trapezoidal lot; Crema explains that the gallery runs along the old walls and stretches to the courtyard which, although still porticoed, is no longer part of the architectural order.

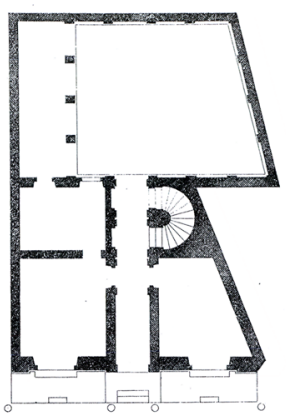

Fig. 4. Top: Plan of a

house in Via Alessandrina (Letarouilly 1868, tav. 26) Bottom: House in Via Alessandrina, survey by L. Crema.
Plan d'une Maison Yia Alessandrinal = 1. we

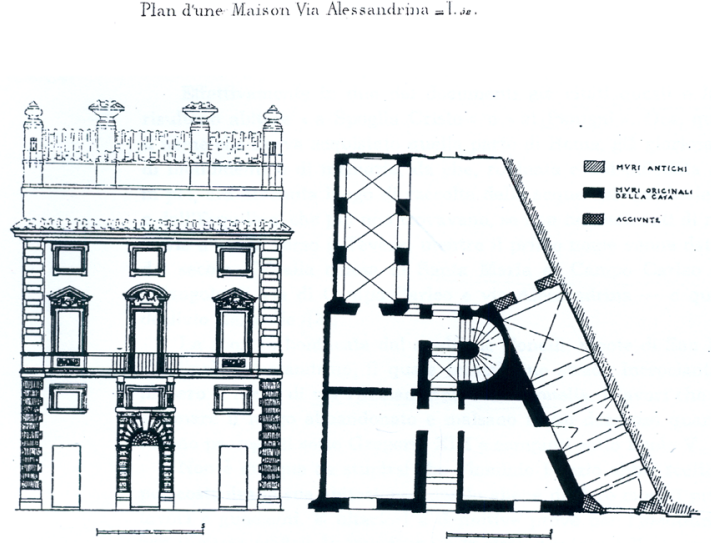

Crema also provides a drawing of the original elevation, but without the building to the side which inevitably must have been built along the old walls of the north exedra of the forum of Augustus. We can get an idea of what the two buildings looked like thanks to surveys of the entire stretch of via Alessandrina (and other streets) prior to the demolition implemented by the architect Mascanzoni [5] (figs. 6, 7), one of the professionals who collaborated with Corrado Ricci, the project manager responsible for the demolition and new design of the area as an archaeological site.

The elevation is divided in two: the base and the 'piano nobile' with the mezzanine. Old photographs show that there was another structure above the cornice, perhaps a loggia or a washroom; walls and windows were later added to this structure, making it habitable. In his survey Crema represents it as a tall, open loggia with high crowning pinnacles; the version present in the aforementioned print by Vasi is walled and with windows. 
The horizontal division of the façade is simple and discreet; a stringcourse and small moulding emphasise the windowsills of the 'piano nobile' with their elegant bas-relief decoration. This visual fascia is underscored by the railings of the central balcony.

The rustication covering both corners of the façade continues up to the roof; the lower ashlars are more massive and protruding while those in the upper part are smoother and flat, ultimately turning into an ornamental moulding that instead of emphasising the corner, the allusive corner, gradually dematerialises it upwards. The rustication, made up of rectangles alternatively narrower and wider, forms an outer limit, a nuanced edge, a sort of interpenetration underscoring continuity with the street façade.

The big rusticated chiaroscuro mass of the entrance door together with the volume of the balcony resting on sturdy decorated brackets framing the central window of the mezzanine produce an interlocking soaring ensemble reminiscent of the exemplary solution used for another entrance door, the one in palazzo Serlupi Crescenzi in via del Seminario designed in 1585 by Giacomo della Porta.

This small house reveals a convergence of echoes and ideas from other experiences intersecting more or less in the distant past and bearing witness to Flaminio Ponzio's dynamic creative participation; according to several authoritative scholars his sensitivity and restraint as an architect places him amongst those who heralded the shift from renaissance and mannerist solutions to ones that are more strictly baroque.

Fig. 5.Vasi's print of S. Maria in Campo Carleo, Piazza Campitelli (Vasi 1756) with Flaminio Ponzio's house highlighted in reddish brown.

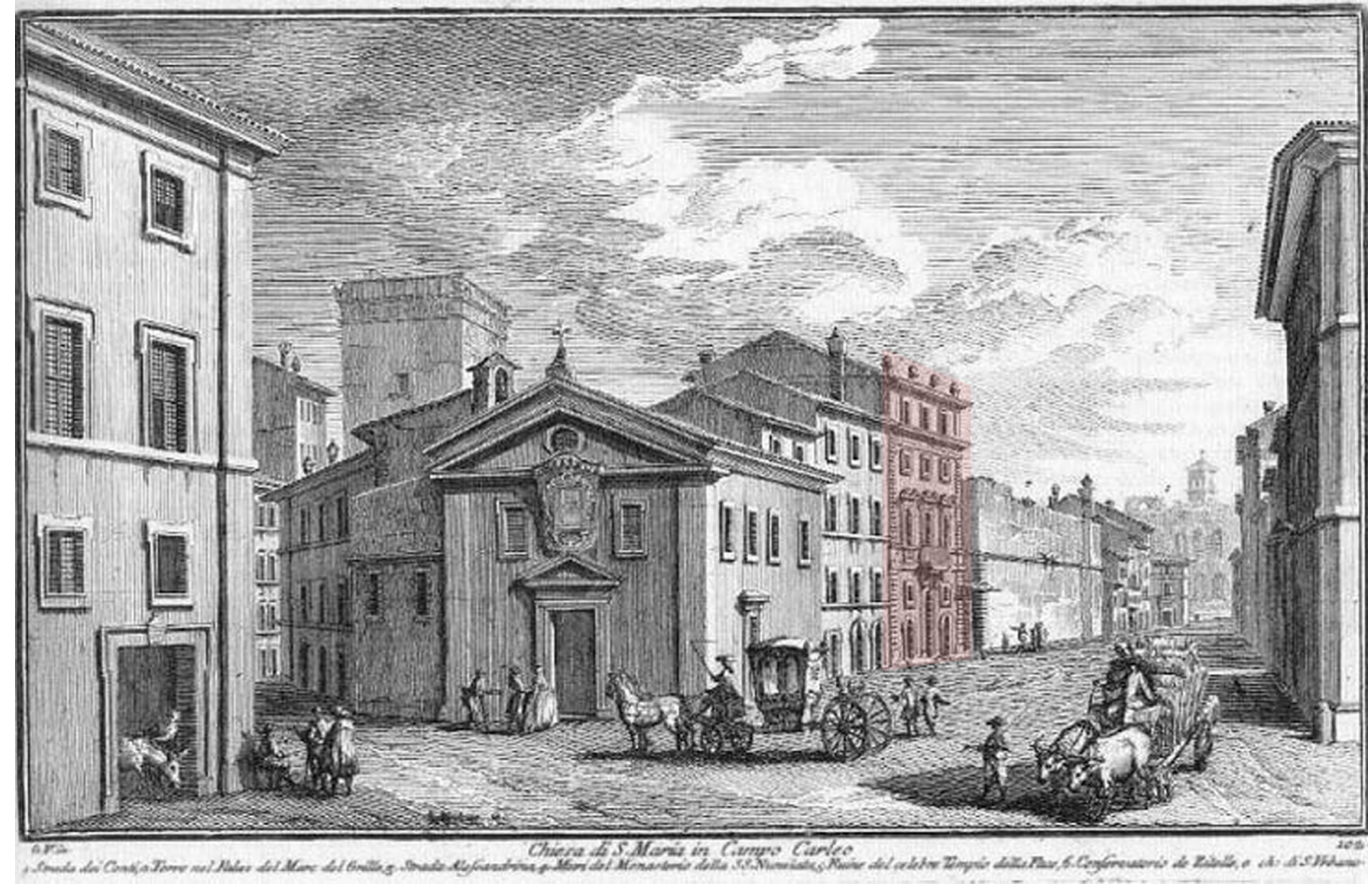

Transposition, i.e., the demolition and reassembly of the house elsewhere

Although Crema states that "the building will be rebuilt", in actual fact only the façade was reconstructed [6]. Part of it disappeared and was very probably completely lost, thus destroying the synthesis, motivation, formative unity and architectural intent. White published the plan of the new building to which the copy of the façade of Flaminio Ponzio's house now belongs it is easy to observe the completely different, disproportionate and abnormal planimetric layout (fig. 8). 
Fig. 6. Surveys of the elevations in Via Alessandrina before the demolitions executed by the architect A. Mascanzoni [Prisco, Mercurio 1982].

Fig. 7. Map of the papal cadastre showing the lots occupied by Flamini Ponzio's house [Prisco, Mercurio 1982].
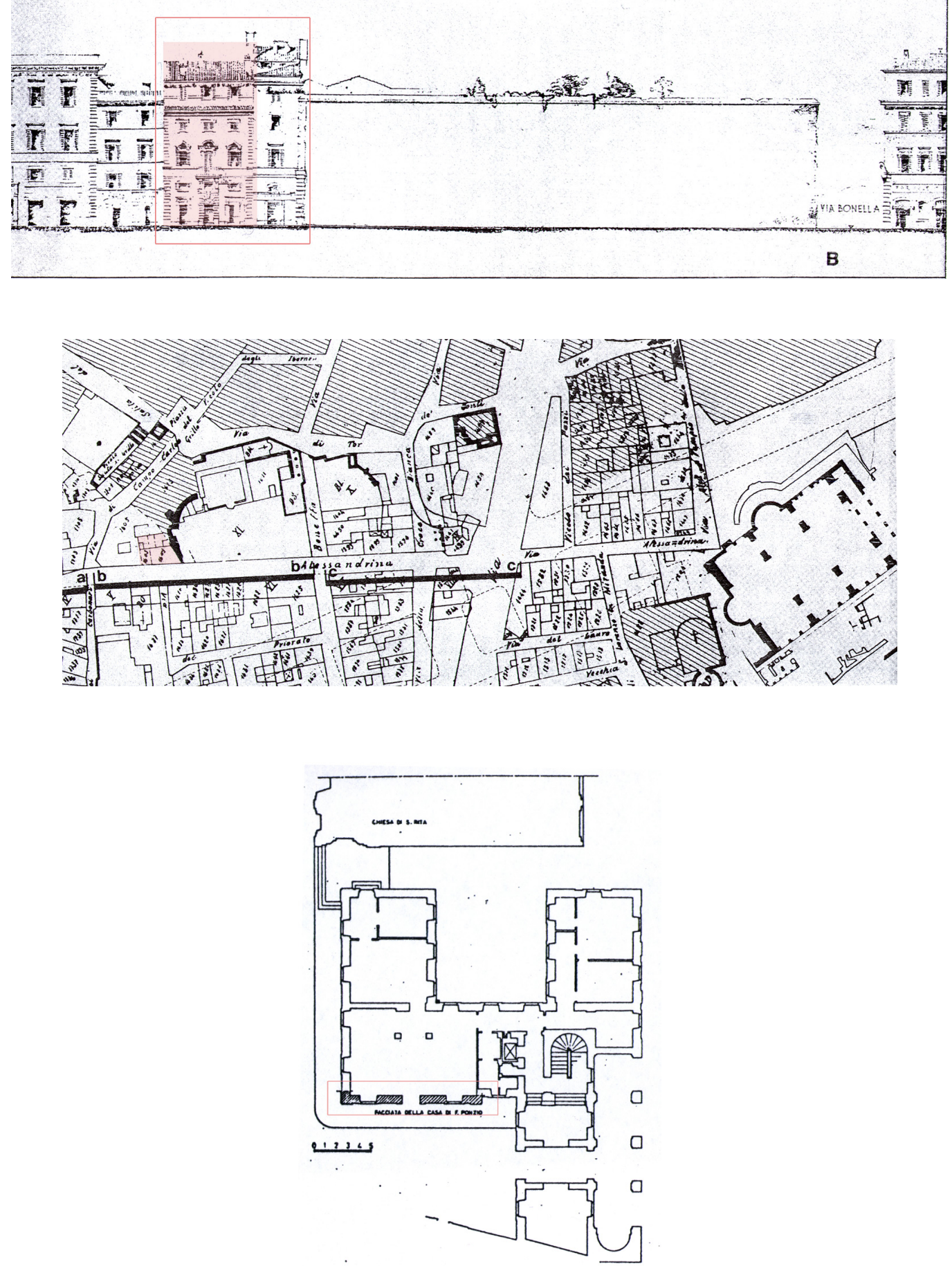
Fig. 9.Top: Piazza Campitelli as it is now; the façade of the building in the background is the rebuilt faccade of Flaminio Ponzio's house. Bottom: a print by Giuseppe vasi showing in the ackground what the changes were mad changes were made in

Fig. 10. Photograph of Piazza Campitelli as it is today (anno 2020).

Furthermore, disorientation determined the disappearance or at least the final modification of the perception of Ponzio's façade due to the fact that it is no longer part of a distinctly longitudinal street façade but is now in a different location, currently an important part of the buildings giving onto Piazza Campitelli (fig. 9).

However, the reconstruction was based on a series of later interpretations; the survey to decide which was Flaminio Ponzio's original design (the one to be saved), the interpretation of its transportation and construction. The architectural ensemble and the details are included and omitted; these decisions are inevitably linked to the period when they were taken.
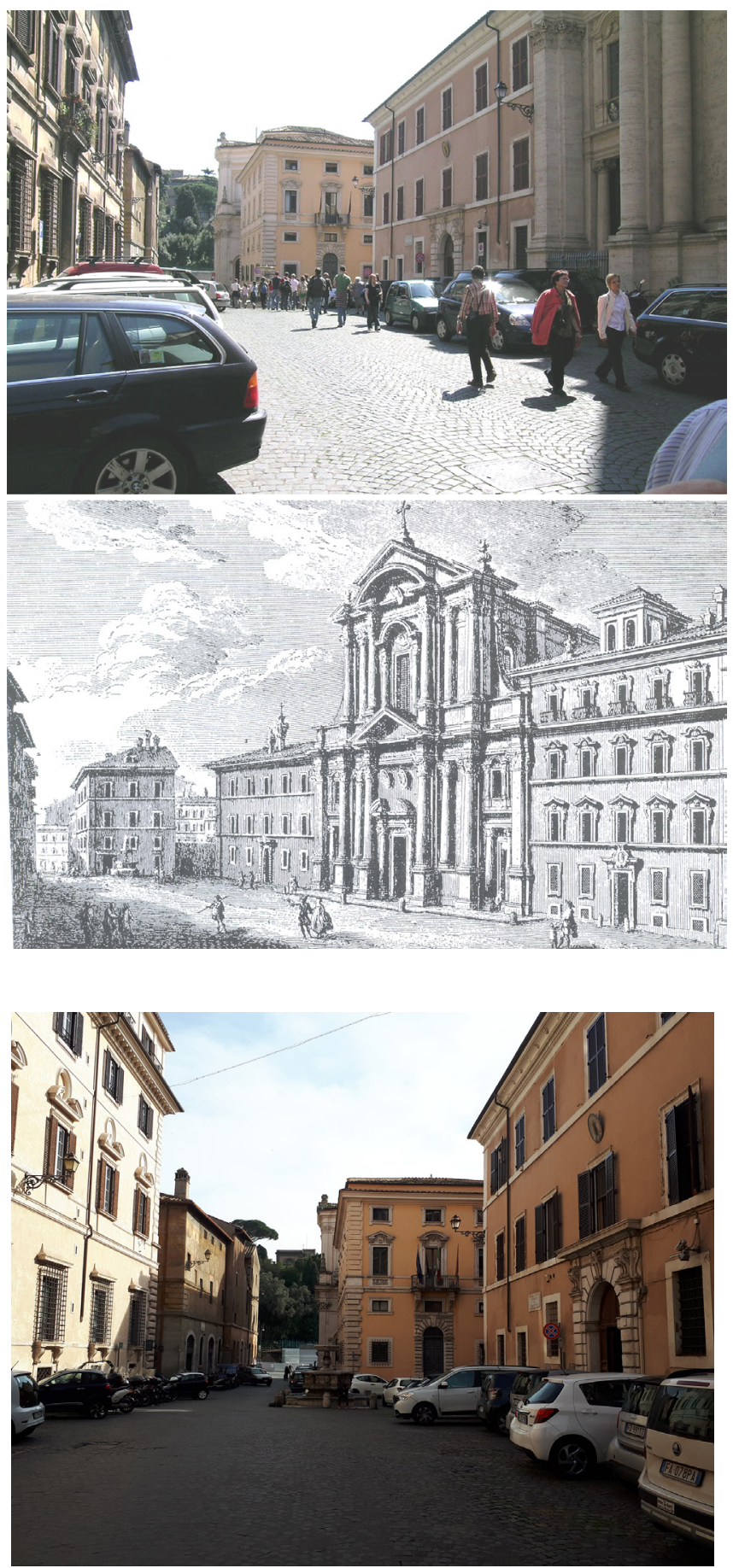
For example, observe the side openings on the ground floor; they are framed windows and not doors as in the old photographs and twentieth-century surveys. As mentioned earlier, the drawn windowsills make it easy to assume that these openings were in fact windows; even Crema confirms this hypothesis. In fact, careful observation of the details of the entire design of the façade reveal that the ground floor openings have no door frames, which is rather unusual. It appears that the rebuilder did not wish to just rebuild the façade, but probably intended to restore Flaminio Ponzio's original design based on available iconographic material (fig. 10).

The rebuilt façade looks like a fake, or better still a copy (reference is to an essay by Cesare Brandi [Brandi 1963] [7]: in fact, we are no longer looking at the original design of this work of art, but at a reproduction which we should not presume to consider an original.

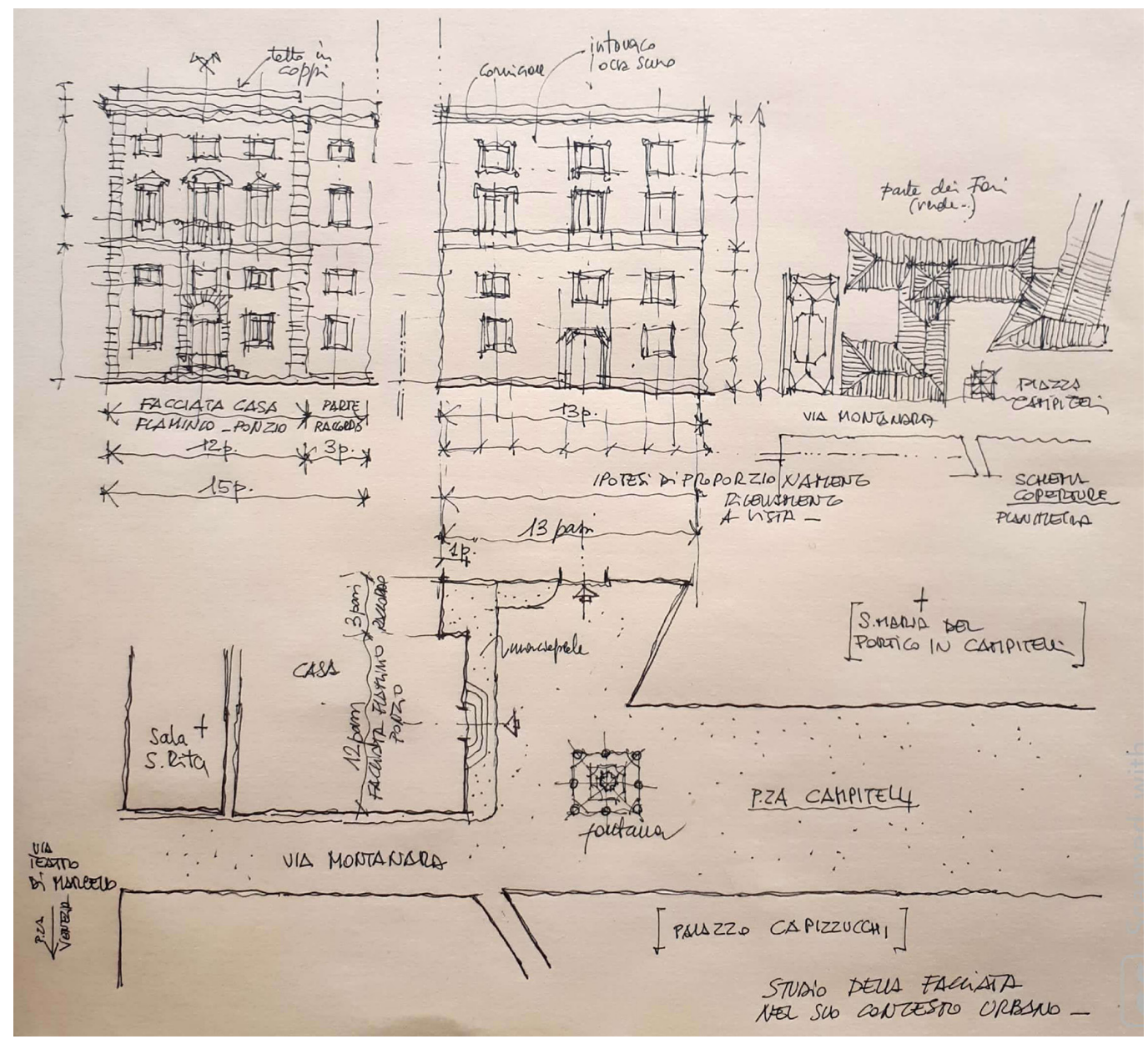

Final considerations, conclusions

Although there are numerous ways in which we can study and reflect on changes to the city, the drawing process has shown that, even in this complex analysis, it is one of the most structured and sensible knowledge-gathering methods because it allows us to navigate the historical events that have revolutionised urban spaces. The relationship between drawing and language grips the draughtsman completely: it is a slow, patient and systematic endeavour (figs. I I, 12).

Memory is the thin red line running through this study; it involved learning about the different data conveyed by an external environment through the organs of sense and then elaborated by the brain in the form of experience in order to understand these events and develop an intellect and ingenuity. 
This critical interpretation has used perceptive aspects to interpret the new urban relationships triggered by the changes and assume their many meanings even from the building's architectural elements.

In this case memory is committed to written and drawn documents, old photographs and the stratification of places which we exploited to develop a plan that took into consideration aspects that differ from those of current urban restoration in which transformations have to consider the history and essence of places. Drawing enables us to analyse the present and make it dialogue graphically and analytically with the past, thereby creating a link. In this case, it involved a partial relocation of Flaminio Ponzio's building since only the façade of the house he designed was actually rebuilt. It was originally located along a straight street next to the wall of the convent of St. Annunziata (also demolished). Ponzio's building was perceptively reduced to just the façade which repeated the rhythmic pattern of other façades along the street; it had no annexes except itself and did not emerge from the linearity of the road. Since we know the history of the building and its migration, we can use drawing to analyse our perception of the building relocated in the more recent urban architectural scenario. We can also study the quality of the architectural elements that were rebuilt and check/compare them against drawings and photographs.

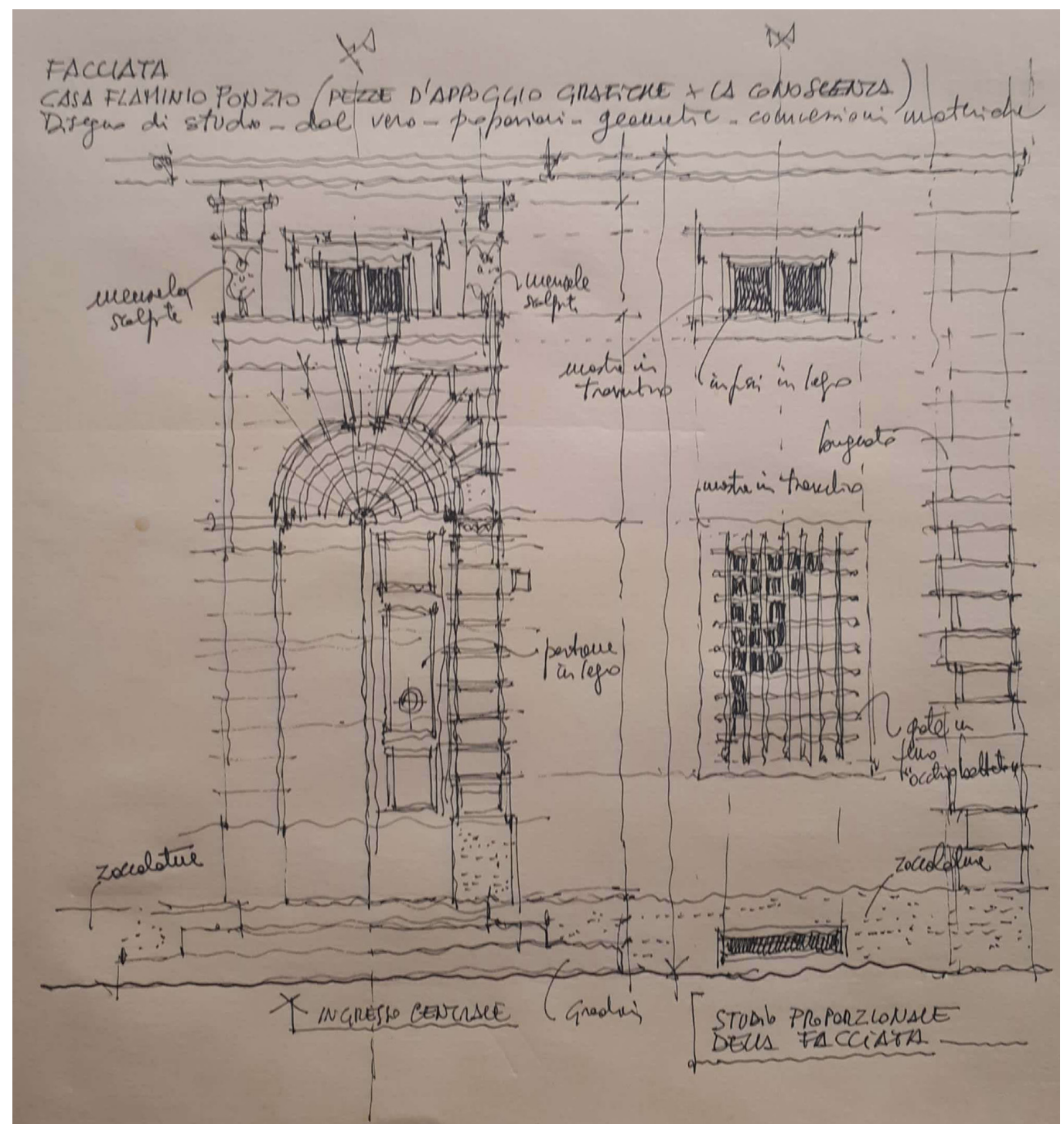


Even at first glance an observer can note that the façade is orthogonal to the street on which the avant-corps has been placed. This flattens the perception of the mouldings and above all exposes the sides and corners which do not appear to be designed harmoniously. Another element that emerges regarding its insertion in the surroundings, especially thanks to the graphic analysis, is the distortion of the proportions between the rectangle of the façade in question, the ones next to it, and the ones facing it.

The sense of disorientation and fixity one feels when there are no nuances of history and memory becomes tangible in drawing, that explains, narrates and, in some cases such as this, reveals the perceptive contradictions of transformations, such as this one, which has luckily been graphically documented.

\section{Notes}

[I] Old maps of Rome by A.P. Frutaz, Le Piante di Roma, Roma, 1962, vol. II: Map by Greuter, 1618; Map by Maggi, 1625; Map by Matteo Gregorio De Rossi, I668; Map by G.B. Falda, 1676; Map by Tempesta, 1693; Map of Rome by Nolli, 1748; Map by Ruga, 1818

[2] The philosophical theory developed by Luigi Pareyson is cited repeatedly by Benedetti and other scholars in an attempt to understand the formative laws of artworks or architecture, which is the same thing. In this case the author provides a possible, hypothetical relationship between the type and the building in question, created due to a positive imitative, operative and creative process.

[3] Plan of the house in via Alessandrina [Letarouilly I 868, tav. 26].

[4] Stampa del Vasi di S. Maria in Campo Carleo, Piazza Campitelli [Vasi 1756]. In actual fact Flaminio Ponzio's house was the second to last before the high wall around the orchard of St. Annunziata; the last house along the block was another building it is here that the new entrance was located.

[5] Elevation along via Alessandrina drafted by the architect A. Mascalzoni before demolition [Prisco, Mercurio 1982, p. 90].

[6] Regarding Piazza Campitelli: "The façade of the modern building at number 6 reflects the reassembly of the façade of the Casa di Flaminio Ponzio built according to his design in 1600 in Via Alessandrina and demolished in 1933 to create Via dell'Impero". Touring Club Italiano (2004). Roma. Milano:Touring Club Italiano, p. 494.

[7] Brandi 1963: Falsificazione in Appendix

\section{References}

Benedetti Sandro (1993). Fuori dal Classicismo. Il sintetismo nell'architettura del Cinquecento. Roma: Bonsignori.

Brandi Cesare (1963). Teoria del restauro. Torino: Einaudi.

Chiavoni Emanuela (2014). Drawings on paper. Digital historical archives of the former Radaar Department at the University Sapienza School of Architecture in Roma. In SCIRES-IT, 4, 2, 20I 4, pp. I I7- 126.

Chiavoni Emanuela, Diacodimitri Alekos, Di Pietro Martinelli Paolo (20 I 8). New Fruition Possibilities for the Historical Archive of Architectural Drawings in Rome. In Inglese Carlo, Ippolito Alfonso (eds.). Analysis, Conservation, and Restoration of Tangible and Intangible Cultural Heritage. Hershey PA (USA): IGl Global, 20 I 8, pp. 403-430.

Delli Sergio (2007). Le strade di Roma. Roma: Newton Compton.

Docci Mario, Maestri Diego (2009). Manuale di rilevamento architettonico e urbano. Roma: Laterza.

Letarouilly Paul ( 1795- | 855). Edifices de Rome moderne. Palais et Maisons, I. London: J.Tiranti \& co.

Magni Giulio (19| |-19|3). || Barocco a Roma nell'architettura e nella scultura decorativa. Torino: Crudo. Mazio Luigi ( 1872). Studi storici, letterari e filosofici. Roma: Editr. Romana.

Prisco Luigi, Mercurio Giovanni (1982). Via Alessandrina a Roma: assenza del passato? In Storia architettura, 2, 1982, 5, pp. 85-98. Vasi Giuseppe (1747-176I). Delle Magnificenze di Roma Antica e Moderna.

\section{Authors}

Gaia Lisa Tacchi, Sapienza Università di Roma, gaialisa.tacchi@uniroma l.it

Emanuela Chiavoni, Sapienza Università di Roma, emanuelachiavoni.uniromal it

To cite this chapter.Tacchi Gaia Lisa, Chiavoni Emanuela (2020). Citazioni architettoniche e urbane. La facciata della casa di Flaminio Ponzio a Via Alessandrina/Architectural and urban citations. The façade of Flaminio Ponzio's House in Via Alessandrina. In Arena A., Arena M., Brandolino R.G., Colistra D., Ginex G., Mediati D., Nucifora S., Raffa P. (a cura di). Connettere. Un disegno per annodare e tessere. Atti del $42^{\circ}$ Convegno Internazionale dei Docenti delle Discipline della Rappresentazione/Connecting. Drawing for weaving relationships. Proceedings of the 42th International Conference of Representation Disciplines Teachers. Milano: FrancoAngeli, pp. 2758-2777. 